\title{
Differential Activation of Orexin Neurons by Antipsychotic Drugs Associated with Weight Gain
}

\author{
Jim Fadel,“ Michael Bubser, ${ }^{\star}$ and Ariel Y. Deutch \\ Departments of Psychiatry and Pharmacology and Centers for Molecular Neuroscience and Integrative and Cognitive \\ Neuroscience, Vanderbilt University School of Medicine, Nashville, Tennessee 37212
}

\begin{abstract}
Weight gain is one side effect of many antipsychotic drugs (APDs). A small number of lateral hypothalamic/perifornical area (LH/PFA) neurons express the orexins, peptides that are critically involved in body weight regulation and arousal. We examined the ability of APDs to activate orexin neurons, as reflected by induction of Fos. APDs with significant weight gain liability increased Fos expression in orexin neurons, but APDs with low or absent weight gain liability did not. The weight gain liability of APDs was correlated with the degree of Fos induction in orexin neurons of the lateral LH/PFA. In contrast, amphetamine, which causes weight loss, increased Fos expression in
\end{abstract}

orexin neurons of the medial but not lateral LH/PFA. We compared the effects of amphetamine and clozapine, an APD with weight gain liability, on orexin neurons innervating the prefrontal cortex. Clozapine induced Fos in $75 \%$ of the orexin neurons that project to the cortex, but amphetamine induced Fos in less than a third of these cells. These data suggest that APDinduced weight gain is associated with activation of distinct orexin neurons and emphasize the presence of anatomically and functionally heterogeneous populations of orexin neurons.

Key words: amphetamine; clozapine; dopamine; haloperidol; prefrontal cortex; weight gain
Treatment with many antipsychotic drugs (APDs) is associated with significant weight gain (Allison et al., 1999; Wetterling and Mussigbrodt, 1999; Taylor and McAskill, 2000; Allison and Casey, 2001). Among the long-term consequences of APD-induced weight gain are increased risk for cardiovascular disease and type II diabetes, and weight gain can hamper social integration and may lead to treatment noncompliance. Various hypotheses concerning the pharmacological basis of APD-induced weight gain have been advanced (Wetterling and Mussigbrodt, 1999; Casey and Zorn, 2001), but the cellular targets of APDs that induce weight gain are unknown.

The orexins (hypocretins) are peptides expressed only in neurons of the classical "feeding area" of the lateral hypothalamus and perifornical area (LH/PFA; de Lecea et al., 1998; Sakurai et al., 1998). Despite the small number of orexin cells, orexin axons are distributed throughout the brain (Peyron et al., 1998; Date et al., 1999). The orexins are potent regulators of feeding and other metabolic processes and of arousal (Kilduff and Peyron, 2000; Sutcliffe and de Lecea, 2000; Willie et al., 2001); in addition, intracerebral orexin administration increases food intake (Edwards et al., 1999).

Dopamine (DA) also plays important roles in feeding and arousal (Terry et al., 1995; Meguid et al., 2000). We have recently described a dense projection from orexin-containing neurons in the LH/PFA to the midbrain A10 DA neurons and an overlap of orexin- and dopamine-containing axons in the rat forebrain (Fadel and Deutch, 2002). These observations suggest interac-

Received Feb. 11, 2002; revised March 25, 2002; accepted May 6, 2002.

This work was supported by National Alliance for Research on Schizophrenia and Depression Young Investigator Awards (J.F., M.B.), Grants MH 45124 and MH 57995 (A.Y.D.), and National Parkinson Foundation Center of Excellence at Vanderbilt University. We thank Eli Lilly and Company and Pfizer, Inc. for olanzapine and ziprasidone, respectively, and Tamara Altman for assistance with figure preparation.

*J.F. and M.B. contributed equally to this work.

Correspondence should be addressed to Ariel Y. Deutch, Psychiatric Hospital at Vanderbilt, Suite 313, 1601 Twenty-Third Avenue South, Nashville, TN 37212. E-mail: ariel.deutch@mcmail.vanderbilt.edu.

Copyright (C) 2002 Society for Neuroscience $0270-6474 / 02 / 226742-05 \$ 15.00 / 0$ tions between DA and orexin, consistent with the finding that orexin-elicited locomotion is blocked by DA receptor antagonists (Nakamura et al., 2000).

Dopamine receptor blockade contributes to both therapeutic and side effects of APDs. The assessment of drug-induced changes in expression of immediate-early genes such as c-fos has been a valuable tool for delineating the sites of action of APDs (see Deutch, 1996). To determine if APDs that cause weight gain activate orexin neurons, we monitored Fos induction in orexin neurons, and we compared the effects of APDs with amphetamine, which decreases food intake.

\section{MATERIALS AND METHODS}

Subjects. Adult male Sprague Dawley rats (Harlan, Birmingham, AL) were group-housed under a $12 \mathrm{hr}$ light/dark cycle (lights on at 6:00 A.M.) with food and water available ad libitum. All experiments were performed between 9:00 A.M. and 2:00 P.M. and were in accord with the Guide for the Care and Use of Laboratory Animals, as promulgated by the National Institutes of Health.

Drugs. All drugs were obtained from Sigma (St. Louis, MO), except for olanzapine (Eli Lilly, Indianapolis, IN) and ziprasidone (Pfizer, Groton, $\mathrm{CT})$. Clozapine $(10$ and $30 \mathrm{mg} / \mathrm{kg}$ ), chlorpromazine $(25 \mathrm{mg} / \mathrm{kg})$, fluphenazine $(1.5 \mathrm{mg} / \mathrm{kg})$, haloperidol $(1.0 \mathrm{mg} / \mathrm{kg})$, olanzapine $(5.0 \mathrm{mg} / \mathrm{kg})$, and D-amphetamine $(1.5 \mathrm{mg} / \mathrm{kg}$ ) were dissolved in acidified water (final pH 5.5-6.0); risperidone $(2 \mathrm{mg} / \mathrm{kg})$ and ziprasidone $(12.5 \mathrm{mg} / \mathrm{kg})$ were suspended in $20 \%$ cyclodextrin. The doses were selected on the basis of clinical equivalency (Bubser and Deutch, 2002). Because APD-induced weight gain is not related to the dose of a particular APD (Allison and Casey, 2001; Basson et al., 2001), we tested one dose of each APD, except in an initial experiment with clozapine.

For each drug tested, corresponding animals were injected with the appropriate vehicle on the same day. The different vehicles did not result in different degrees or patterns of Fos expression in orexin neurons.

Experimental procedures. We compared the ability of four APDs that cause significant weight gain (clozapine, olanzapine, chlorpromazine, and risperidone) and three APDs with low or absent weight gain liability (haloperidol, fluphenazine, and ziprasidone) to induce Fos in orexin neurons.

Amphetamine decreases food intake and causes weight loss. However, methamphetamine increases Fos expression in orexin neurons (Estabrooke et al., 2001). We determined if the effects of amphetamine and APDs are manifested in different populations of orexin neurons by 
retrogradely labeling LH/PFA neurons that project to the prefrontal cortex (PFC), which receives convergent orexin and DA innervations (Fadel and Deutch, 2002). We then compared the numbers of retrogradely labeled orexin neurons in which either clozapine $(30 \mathrm{mg} / \mathrm{kg})$ or amphetamine $(1.5 \mathrm{mg} / \mathrm{kg})$ induced Fos. Animals were anesthetized, and $200 \mathrm{nl}$ of a $1 \%$ solution of the retrograde tracer cholera toxin $\mathrm{B}(\mathrm{CTb}$; List Biological Laboratories, Campbell, CA) was injected into the PFC. Ten days later rats were injected with amphetamine or clozapine.

Immunohistochemistry. Two hours after drug treatment, rats were anesthetized and perfused; brains were postfixed, cryoprotected, and frozen sections were cut through the hypothalamus. A dual immunoperoxidase protocol (Deutch et al., 1991; Scruggs et al., 2000) was followed to reveal Fos-like immunoreactive (-li) nuclei in orexin-li neurons, using a goat anti-Fos antibody (1:4000; Santa Cruz Biotechnology, Santa Cruz, CA) and a rabbit anti-orexin A antibody (1:3000; Calbiochem, San Diego, CA). We also determined if Fos was induced in LH/PFA cells expressing melanin concentrating hormone $(\mathrm{MCH})$, using a chicken anti-MCH antibody (1:3000; Peninsula Laboratories, San Carlos, CA).

To determine if amphetamine and clozapine induce Fos in orexin cells that innervate the PFC, sections were subjected to an immunoperoxidase method that stains Fos-li nuclei black (Deutch et al., 1991). Sections were then incubated in orexin A and CTb antisera, followed by incubation in CY2- and CY3-labeled secondary antibodies. Black Fos-li nuclei were clearly visible when surrounded by cytoplasmic orexin- and/or CTb fluorescence (see Fig. 4).

Cell counts and data analysis. General cell counting methods follow our previously described methods (Scruggs et al., 2000). The number of single-labeled (orexin or Fos), double-labeled (orexin plus Fos, CTb plus Fos, or orexin plus CTb), or triple-labeled (orexin plus CTb plus Fos) cells was determined at two rostrocaudal levels of the LH/PFA encompassing the greatest number of orexin neurons (see Fig. 1). Cells were counted in the medial and lateral LH/PFA, as defined by a vertical line bisecting the fornix (see Fig. 1); the mean numbers of orexin neurons in the medial and lateral LH/PFA did not differ $\left(t_{188}=0.964\right.$; NS $)$.

Data were analyzed by ANOVA followed by Bonferroni $t$ tests when indicated or by unpaired $t$ tests (amphetamine effects and comparison of amphetamine and clozapine).

\section{RESULTS}

\section{Antipsychotic drug-induced Fos expression in orexin neurons}

Both 10 and $30 \mathrm{mg} / \mathrm{kg}$ clozapine significantly increased the percentage of orexin neurons expressing Fos $\left(F_{(2,10)}=18.3 ; p \leq\right.$ 0.001 ), but not in a dose-related manner. Clozapine did not induce Fos in MCH-li neurons of the LH/PFA (see Fig. 4).

A significant treatment effect of APDs on Fos expression in orexin cells was seen in both the medial $\left(F_{(7,71)}=17.9 ; p \leq\right.$ $0.0001)$ and lateral $\left(F_{(7,72)}=18.0 ; p<0.0001\right)$ LH/PFA (Fig. 1). Clozapine, olanzapine, risperidone, and chlorpromazine significantly increased the percentage of orexin cells expressing Fos compared with vehicle (Fig. 1). In contrast, ziprasidone, haloperidol, and fluphenazine did not increase Fos expression in orexin neurons.

The APDs that induced Fos in orexin-li neurons did so to different degrees in the lateral and medial LH/PFA. In the lateral LH/PFA, Fos was induced in orexin cells to a significantly greater degree in olanzapine-treated animals than chlorpromazine- and risperidone-injected rats. Clozapine also induced Fos in a significantly higher percentage of lateral LH/PFA orexin cells than did risperidone and tended to exert a greater effect than chlorpromazine $(p=0.0502)$. In contrast, the four APDs that increased Fos expression did so to a similar degree in the medial LH/PFA. There was, however, a different pattern of changes when Fos expression was examined in non-orexin neurons: APDs that cause weight gain induced Fos in non-orexin neurons of the medial LH/PFA, whereas in the lateral LH/PFA only clozapine and olanzapine increased the density of these cells (Table 1).
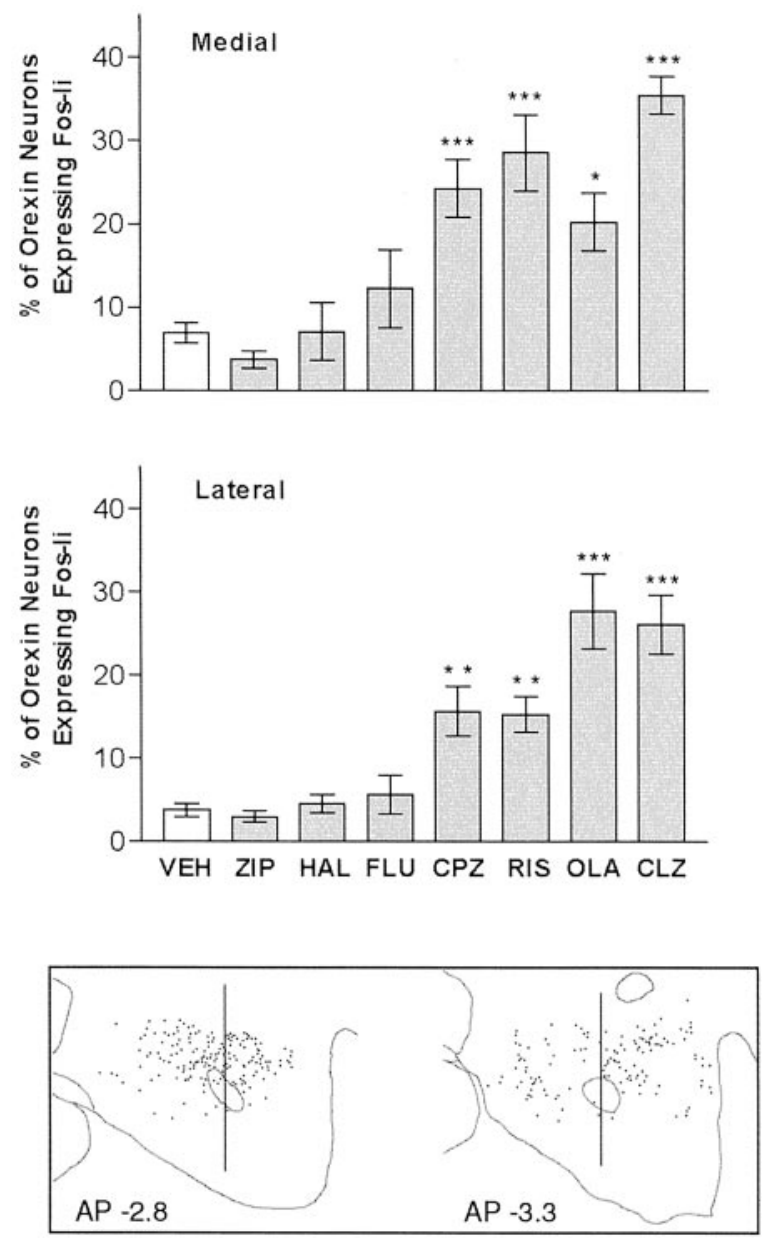

Figure 1. Orexin-li neurons expressing Fos were counted in the medial and lateral LH/PFA at two levels of the hypothalamus (bottom). The percentages of orexin neurons expressing Fos were significantly greater after administration of APDs with high weight gain liability (CLZ, clozapine; $O L A$, olanzapine; $R I S$, risperidone; $C P Z$, chlorpromazine) than after challenge with APDs that cause relatively little weight gain (ZIS, ziprasidone; FLU, fluphenazine; $H A L$, haloperidol). ${ }^{*} p \leq 0.01 ;{ }^{* *} p \leq$ $0.001 ;{ }^{* * * *} p \leq 0.0001$.

\section{Amphetamine actions on Fos expression in orexin neurons}

Amphetamine significantly increased the percentage of orexin cells expressing Fos-li in the medial $\left(t_{9}=2.64 ; p \leq 0.05\right)$ but not

Table 1. Density of non-orexin neurons that express Fos in response to antipsychotic drug administration in the medial and lateral LH/PFA

\begin{tabular}{|c|c|c|}
\hline & Medial & Lateral \\
\hline & Fos-li cells $/ \mathrm{mm}^{2}$ & \\
\hline Vehicle & $32.2 \pm 5.1$ & $21.4 \pm 3.5$ \\
\hline Ziprasidone & $57.6 \pm 5.6$ & $29.8 \pm 3.5$ \\
\hline Haloperidol & $42.2 \pm 9.2$ & $34.5 \pm 8.9$ \\
\hline Fluphenazine & $43.9 \pm 15.5$ & $28.1 \pm 11.6$ \\
\hline Chlorpromazine & $64.6 \pm 7.5^{*}$ & $23.0 \pm 3.4$ \\
\hline Risperidone & $71.3 \pm 6.4^{* *}$ & $39.6 \pm 5.0$ \\
\hline Olanzapine & $90.4 \pm 10.8^{* *}$ & $44.8 \pm 5.5^{*}$ \\
\hline Clozapine & $89.9 \pm 8.2^{* * *}$ & $51.5 \pm 8.2^{* *}$ \\
\hline
\end{tabular}

${ }^{*} p \leq 0.05 ; *{ }^{*} p \leq 0.01 ; * * * p \leq 0.001$. 

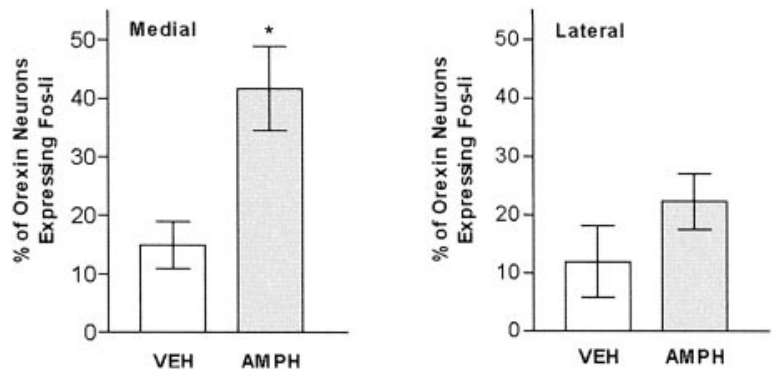

Figure 2. Amphetamine induced Fos in orexin neurons of the medial but not lateral $\mathrm{LH} / \mathrm{PFA} .{ }^{*} p \leq 0.02$.
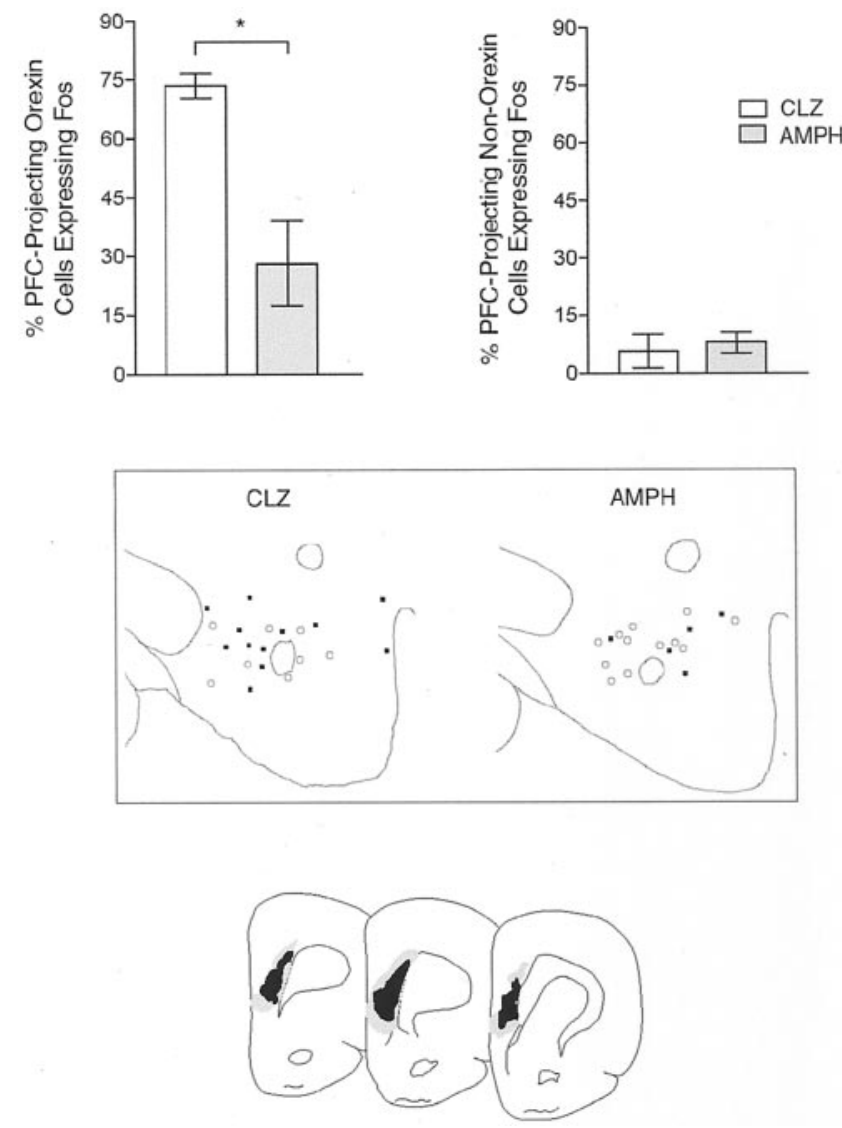

Figure 3. Clozapine induced Fos to a significantly greater degree in orexin neurons that project to the prefrontal cortex than did amphetamine $(A M P H)$ (top left). There was no difference in the degree to which the two drugs induced Fos in non-orexin LH/PFA cells that innervate the PFC (top right). Chartings of representative sections from animals treated with clozapine or amphetamine (middle row) show retrogradely labeled orexin neurons that expressed Fos as filled circles; open circles mark orexin neurons that project to the cortex but do not express Fos. Maximal (stipple) and minimal (black) cholera toxin B deposits into the PFC are shown at the bottom. ${ }^{*} p \leq 0.01$.

the lateral $\left(t_{9}=1.32\right.$; NS) LH/PFA (Fig. 2). Amphetamine did not induce Fos in MCH-li cells $\left(t_{8}=1.48\right.$; NS), nor in non-orexin neurons (medial: $t_{10}=1.72$, NS; lateral: $t_{10}=1.32$, NS).

\section{Effects of clozapine and amphetamine on orexin neurons that innervate the prefrontal cortex}

Cortical $\mathrm{CTb}$ deposits involved the prelimbic, infralimbic, and occasionally shoulder cortices, and labeled scattered cells in the LH/PFA (Fig. 3), of which $32.0 \pm 2.3 \%$ were orexin-
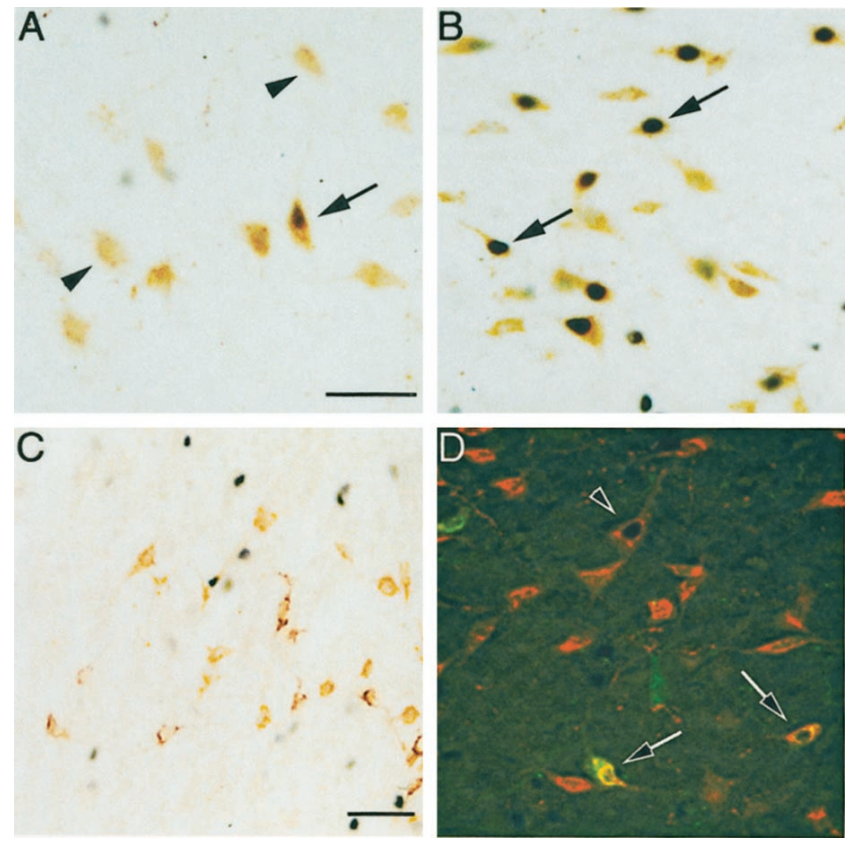

Figure 4. Photomicrographs showing Fos-li nuclei in orexin-li neurons. In a vehicle-treated rat only one orexin cell contains a Fos-li nucleus (arrow), although many orexin-li cells (arrowheads) are visible. In contrast, many Fos positive orexin neurons (arrows) are seen in a section from a clozapine-treated animal. Clozapine does not induce Fos in $\mathrm{MCH}-\mathrm{li}$ neurons $(C)$. $D$ shows cells retrogradely labeled from the prefrontal cortex (green) and orexin-li neurons (red). An orexin neuron that expresses Fos but does not innervate the PFC is marked by an arrowhead. Orexin cells that project to the PFC appear yellow-orange, and one of these (arrow) contains a clearly visible Fos-li nucleus.

immunoreactive. The mean number of retrogradely labeled cells in the two sections through the LH/PFA did not differ significantly between clozapine-treated $(81 \pm 19)$ and amphetamine-treated $(63 \pm 11)$ rats $\left(t_{5}=0.42 ; \mathrm{NS}\right)$.

Amphetamine and clozapine differed markedly in the degree to which they induced Fos in orexin neurons projecting to the PFC $\left(t_{5}=3.48 ; p \leq 0.02\right)$. Fos was expressed in $\sim 75 \%$ of the retrogradely labeled orexin neurons in clozapine-treated animals; amphetamine induced Fos in $<30 \%$ of these cells (Figs. 3, 4). Clozapine and amphetamine did not differ in the degree to which they induced Fos in non-orexin-containing LH/PFA cells that innervate the $\operatorname{PFC}\left(t_{5}=0.45 ; p=0.67\right)$ (Fig. 3).

\section{DISCUSSION}

Fos expression was induced in orexin neurons by APDs that cause significant weight gain but not by those APDs with low weight gain liability. However, amphetamine also activated orexin neurons. This paradox was resolved by the finding that clozapine markedly increased Fos expression in orexin neurons that innervate the PFC, whereas amphetamine had a weak effect on this population of orexin neurons.

\section{Relation of antipsychotic drug-induced weight gain} and Fos induction in orexin neurons

Treatment with clozapine, olanzapine, risperidone, and chlorpromazine causes significant weight gain, whereas haloperidol, fluphenazine, and ziprasidone result in minimal weight gain (Wetterling and Mussigbrodt, 1999; Taylor and McAskill, 2000; Allison and Casey, 2001). We found that APDs that increase weight activate orexin neurons, as reflected by Fos induction. 
Conversely, APDs that do not cause weight gain do not activate orexin cells. APDs that cause weight gain did not activate the $\mathrm{MCH}-\mathrm{li}$ neurons of the $\mathrm{LH} / \mathrm{PFA}$, although $\mathrm{MCH}$ also increases food intake (Edwards et al., 1999).

The degree to which clozapine induced Fos in orexin neurons was not dose-dependent; this mirrors the clinical situation, in which the amount of weight gained is not related to the dose of a particular APD (Allison and Casey, 2001; Basson et al., 2001). However, different APDs increase weight to different degrees. For example, clozapine and olanzapine cause greater weight gain in adults than chlorpromazine and risperidone (Allison et al., 1999). We found that olanzapine and clozapine exerted greater effects on orexin neurons in the lateral LH/PFA than did chlorpromazine and risperidone. In contrast, amphetamine activated orexin neurons in the medial but not lateral LH/PFA. These observations suggest that orexin neurons in the lateral LH/PFA may be involved in APD-induced weight gain, but medial orexin neurons may subserve other functions.

\section{Mechanisms of antipsychotic drug-induced activation of orexin neurons}

Because clozapine and amphetamine activate different groups of orexin neurons, it is likely that changes in the activity of afferents or hormonal signals to these orexin neurons determine the response. The identity of these afferents is unknown, but may include the PFC and nucleus accumbens, regions that receive dopaminergic projections from the A10 cell group and project to the LH/PFA (Sesack et al., 1989; Heimer et al., 1991). Feeding increases DA release in both the PFC and accumbens (Feenstra and Botterblom, 1996; Taber and Fibiger, 1997; Ahn and Phillips, 1999). Stratford and Kelley (1999) have suggested that the involvement of the accumbens in feeding behavior depends upon glutamatergic projections to the $\mathrm{LH}$.

The receptor mechanisms that subserve APD-induced weight gain are of considerable interest (Basile et al., 2001; Casey and Zorn, 2001). $\mathrm{D}_{2}$ dopamine receptors are probably not crucial, because haloperidol mainly targets $\mathrm{D}_{2}$ receptors in vivo (Schotte et al., 1996) yet causes relatively little weight gain. The four APDs that we tested that increase weight have high affinities for multiple receptors, including $5-\mathrm{HT}_{2 \mathrm{~A} / \mathrm{C}}, \mathrm{D}_{1}$, and $\alpha_{1}$ receptors (Schotte et al., 1996; Zhang and Bymaster, 1999). However, ziprasidone has a similarly rich receptor profile (Zhang and Bymaster, 1999; Casey and Zorn, 2001), suggesting that the aforementioned receptors do not subserve APD-induced weight gain. There is a strong correlation between APD affinities for the histamine H1 receptor and weight gain, suggesting that the $\mathrm{H} 1$ receptor plays an important role (Wirshing et al., 1999).

The receptors that are targeted by APDs that induce weight gain may be present on orexin neurons or on afferents to the orexin neurons, such as neurons of the PFC. Alternatively, peripherally derived signals may be critical. Leptin, which is released from adipose tissue, inhibits food intake (Meister, 2000). The long form of the leptin receptor is localized to the great majority of orexin cells (Iqbal et al., 2001). However, MCH neurons, which are not activated by APDs that cause weight gain, also express the leptin receptor (Iqbal et al., 2001), and there does not appear to be a correlation between the magnitude of APD-induced weight gain and APD-elicited changes in leptin (Melkersson and Hulting, 2001).

Orexin neurons contain other transmitters that may contribute to or be the proximate effector of changes in food intake and metabolism. Although the phenotype of the prepro-orexin knock-out mouse is limited to narcolepsy (Chemelli et al., 1999), transgenic mice with a targeted loss of orexin neurons caused by an ataxin-3 trinucleotide repeat expressed under the orexin promotor are hypophagic as well as narcoleptic (Hara et al., 2001). It is possible that the loss of a transmitter that is colocalized with orexin (Hakansson et al., 1999; Chou et al., 2001) may be the critical factor for weight changes rather than orexin. It is interesting to note that Fos expression in non-orexin-containing neurons was increased in the medial LH/PFA by APDs that cause weight gain; these cells are not localized to a single cytoarchitectonically defined nucleus and probably represent a heterogeneous group of neurons. Future studies will be required to identify the phenotype of these neurons and to determine if there is a correlation between APD-induced activation of any specific type of neuron (other than orexin) and weight gain.

\section{Clinical implications of orexin neurons and the actions of antipsychotic drugs}

Weight gain appears to be correlated positively with clinical response to APDs (Lamberti et al., 1992; Leadbetter et al., 1992; Meltzer et al., 2002). This suggests that activation of orexin neurons projecting to the PFC may be involved in the therapeutic as well as the side effects of some APDs. There appears to be a dopaminergic dysfunction in the PFC in schizophrenia, including a decreased density of the cortical DA innervation (Akil et al., 1999). Intraventricular administration of orexin leads to a dopamine-dependent increase in locomotor activity (Nakamura et al., 2000), and orexin activates certain A10 DA neurons (Uramura et al., 2001), but data on orexin-induced DA release in terminal fields such as the PFC are lacking. Interestingly, APDs that increase Fos expression in orexin neurons also increase DA release in the PFC (Hertel et al., 1996; Li et al., 1998). In contrast, haloperidol neither activates orexin neurons nor evokes DA release in the PFC (Li et al., 1998). The ability of certain APDs to induce weight gain may lead to a better clinical response by increasing cortical DA release through an orexin-dependent mechanism.

\section{Heterogeneity of orexin neurons}

We found that approximately one-third of LH/PFA neurons that were retrogradely labeled from the PFC expressed orexin. Similarly, approximately one-third of orexin cells were retrogradely labeled from the PFC. Thus, despite the very small number of neurons that contribute to the orexin innervation of virtually the entire neuraxis, some orexin neurons have discrete projection targets. We have recently observed that $<5 \%$ of the orexin neurons that innervate the PFC collateralize to innervate the central gray (our unpublished observations), indicating that at least some orexin neurons do not collateralize widely. Thus, one can distinguish distinct groups of orexin neurons on hodological grounds. We found that within a population of orexin neurons defined on the basis of projection target, one can also distinguish functional subsets of neurons by the different responses to clozapine and amphetamine.

The presence of various transmitter receptors differs across orexin neurons and afferents to different orexin neurons vary (Broberger et al., 1998; Elias et al., 1998; Kilduff and de Lecea, 2001). It has been clear that orexin has a number of different functional roles. Nonetheless, most studies have considered the orexin neurons as a unitary group. The present data emphasize the heterogeneous nature of the orexin neurons. Elucidating the regulatory processes that govern the differential activation of orexin neurons will be necessary to reveal fully the functional roles of orexin. 


\section{REFERENCES}

Ahn S, Phillips AG (1999) Dopaminergic correlates of sensory-specific satiety in the medial prefrontal cortex and nucleus accumbens of the rat. J Neurosci 19:RC29.

Akil M, Pierri JN, Whitehead RE, Edgar CL, Mohila C, Sampson AR, Lewis DA (1999) Lamina-specific alterations in the dopamine innervation of the prefrontal cortex in schizophrenic subjects. Am J Psychiatry $156: 1580-1589$.

Allison DB, Casey DE (2001) Antipsychotic-induced weight gain: a review of the literature. J Clin Psychiatry 62:22-31.

Allison DB, Mentore JL, Heo M, Chandler LP, Cappelleri JC, Infante MC, Weiden PJ (1999) Antipsychotic-induced weight gain: a comprehensive research synthesis. Am J Psychiatry 156:1686-1696.

Basile VS, Masellis M, McIntyre RS, Meltzer HY, Lieberman JA, Kennedy JL (2001) Genetic dissection of atypical antipsychoticinduced weight gain: novel preliminary data on the pharmacogenetic puzzle. J Clin Psychiatry 62:45-66.

Basson BR, Kinon BJ, Taylor CC, Szymanski KA, Gilmore JA, Tollefson GD (2001) Factors influencing acute weight change in patients with schizophrenia treated with olanzapine, haloperidol, or risperidone. J Clin Psychiatry 62:231-238.

Broberger C, De Lecea L, Sutcliffe JG, Hokfelt T (1998) Hypocretin/ orexin- and melanin-concentrating hormone-expressing cells form distinct populations in the rodent lateral hypothalamus: relationship to the neuropeptide $\mathrm{Y}$ and agouti gene-related protein systems. J Comp Neurol 402:460-474.

Bubser M, Deutch AY (2002) Differential effects of typical and atypical antipsychotic drugs on striosome and matrix compartments of the striatum. Eur J Neurosci 15:713-720.

Casey DE, Zorn SH (2001) The pharmacology of weight gain with antipsychotics. J Clin Psychiatry 62:4-10.

Chemelli RM, Willie JT, Sinton CM, Elmquist JK, Scammell T, Lee C, Richardson JA, Williams SC, Xiong Y, Kisanuki Y, Fitch TF, Nakazato M, Hammer RE, Saper CB, Yanagisawa M (1999) Narcolepsy in orexin knockout mice: molecular genetics of sleep regulation. Cell 98:347-451.

Chou TC, Lee CE, Lu J, Elmquist JK, Hara J, Willie JT, Beuckmann CT, Chemelli RM, Sakurai T, Yanagisawa M, Saper CB, Scammell TE (2001) Orexin (hypocretin) neurons contain dynorphin. J Neurosci 21:RC168.

Date Y, Ueta Y, Yamashita H, Yamaguchi H, Matsukura S, Kangawa K, Sakurai T, Yanagisawa M, Nakazato M (1999) Orexins, orexigenic hypothalamic peptides, interact with autonomic, neuroendocrine and neuroregulatory systems. Proc Natl Acad Sci USA 96:748-753.

de Lecea L, Kilduff TS, Peyron C, Gao X, Foye PE, Danielson PE, Fukuhara C, Battenberg EL, Gautvik VT, Bartlett FS, Frankel WN, van den Pol AN, Bloom FE, Gautvik KM, Sutcliffe JG (1998) The hypocretins: hypothalamus-specific peptides with neuroexcitatory activity. Proc Natl Acad Sci USA 95:322-327.

Deutch AY (1996) Sites and mechanisms of action of antipsychotic drugs as revealed by immediate-early gene expression. In: Antipsychotics (Handbook Exp Pharmacol 120) (Csernanksy JG, ed), pp 117-161. Berlin: Springer.

Deutch AY, Lee MC, Gillham MH, Cameron DA, Goldstein M, Iadarola MJ (1991) Stress selectively increases fos protein in dopamine neurons innervating the prefrontal cortex. Cereb Cortex 1:273-292.

Edwards CM, Abusnana S, Sunter D, Murphy KG, Ghatei MA, Bloom SR (1999) The effect of the orexins on food intake: comparison with neuropeptide Y, melanin-concentrating hormone and galanin. J Endocrinol 160:R7-12.

Elias CF, Saper CB, Maratos-Flier E, Tritos NA, Lee C, Kelly J, Tatro JB, Hoffman GE, Ollmann MM, Barsh GS, Sakurai T, Yanagisawa M, Elmquist JK (1998) Chemically defined projections linking the mediobasal hypothalamus and the lateral hypothalamic area. J Comp Neurol 402:442-459.

Estabrooke IV, McCarthy MT, Ko E, Chou TC, Chemelli RM, Yanagisawa M, Saper CB, Scammell TE (2001) Fos expression in orexin neurons varies with behavioral state. J Neurosci 21:1656-1662.

Fadel J, Deutch AY (2002) Anatomical substrates of orexin-dopamine interactions: lateral hypothalamic projections to the ventral tegmental area. Neuroscience 111:379-387.

Feenstra MG, Botterblom MH (1996) Rapid sampling of extracellular dopamine in the rat prefrontal cortex during food consumption, handling and exposure to novelty. Brain Res 742:17-24.

Hakansson M, de Lecea L, Sutcliffe JG, Yanagisawa M, Meister B (1999) Leptin receptor- and STAT3-immunoreactivities in hypocretin/orexin neurones of the lateral hypothalamus. J Neuroendocrinol 11:653-663.

Hara J, Beuckmann CT, Nambu T, Willie JT, Chemelli RM, Sinton SM, Sugiyama F, Yagami K, Goto K, Yanagisawa M, Sakurai T (2001) Genetic ablation of orexin neurons in mice results in narcolepsy, hypophagia, and obesity. Neuron 30:345-354.

Heimer L, Zahm DS, Churchill L, Kalivas PW, Wohltmann C (1991) Specificity in the projection patterns of accumbal core and shell in the rat. Neuroscience 41:89-125.

Hertel P, Nomikos GG, Iurlo M, Svensson TH (1996) Risperidone: regional effects in vivo on release and metabolism of dopamine and serotonin in the rat brain. Psychopharmacology (Berl) 124:74-86.

Iqbal J, Pompolo S, Murakami T, Grouzmann E, Sakurai T, Meister B, Clarke IJ (2001) Immunohistochemical characterization of localization of long-form leptin receptor $(\mathrm{OB}-\mathrm{Rb})$ in neurochemically defined cells in the ovine hypothalamus. Brain Res 920:55-64.

Kilduff TS, de Lecea L (2001) Mapping of the mRNAs for the hypocretin/orexin and melanin- concentrating hormone receptors: Networks of overlapping peptide systems. J Comp Neurol 435:1-5.

Kilduff TS, Peyron C (2000) The hypocretin/orexin ligand-receptor system: implications for sleep and sleep disorders. Trends Neurosci 23:359-365.

Lamberti JS, Bellnier T, Schwarzkopf SB (1992) Weight gain among schizophrenic patients treated with clozapine. Am J Psychiatry 149:689-690.

Leadbetter R, Shutty M, Pavalonis D, Vieweg V, Higgins P, Downs M (1992) Clozapine-induced weight gain: prevalence and clinical relevance. Am J Psychiatry 149:68-72.

Li XM, Perry KW, Wong DT, Bymaster FP (1998) Olanzapine increases in vivo dopamine and norepinephrine release in rat prefrontal cortex, nucleus accumbens and striatum. Psychopharmacology (Berl) 136:153-161.

Meguid MM, Fetissov SO, Varma M, Sato T, Zhang L, Laviano A, Rossi-Fanelli F (2000) Hypothalamic dopamine and serotonin in the regulation of food intake. Nutrition 16:843-857.

Meister B (2000) Control of food intake via leptin receptors in the hypothalamus. Vitam Horm 59:265-304.

Melkersson KI, Hulting AL (2001) Insulin and leptin levels in patients with schizophrenia or related psychoses: a comparison between different antipsychotic agents. Psychopharmacology (Berl) 154:205-212.

Meltzer HY, Perry E, Jayathilake K (2002) Clozapine-induced weight gain predicts improvement in psychopathology. Schizophr Res, in press.

Nakamura T, Uramura K, Nambu T, Yada T, Goto K, Yanagisawa M, Sakurai T (2000) Orexin-induced hyperlocomotion and stereotypy are mediated by the dopaminergic system. Brain Res 873:181-187.

Peyron C, Tighe DK, van den Pol AN, de Lecea L, Heller HC, Sutcliffe JG, Kilduff TS (1998) Neurons containing hypocretin (orexin) project to multiple neuronal systems. J Neurosci 18:9996-10015.

Sakurai T, Amemiya A, Ishii M, Matsuzaki I, Chemelli RM, Tanaka H, Williams SC, Richardson JA, Kozlowski GP, Wilson S, Arch JR, Buckingham RE, Haynes AC, Carr SA, Annan RS, McNulty DE, Liu WS, Terrett JA, Elshourbagy NA, Bergsma DJ, Yanagisawa M (1998) Orexins and orexin receptors: a family of hypothalamic neuropeptides and $G$ protein-coupled receptors that regulate feeding behavior. Cell 92:573-585.

Schotte A, Janssen PF, Gommeren W, Luyten WH, Van Gompel P, Lesage AS, De Loore K, Leysen JE (1996) Risperidone compared with new and reference antipsychotic drugs: in vitro and in vivo receptor binding. Psychopharmacology (Berl) 124:57-73.

Scruggs JL, Patel S, Bubser M, Deutch AY (2000) DOI-Induced activation of the cortex: dependence on 5-HT2A heteroceptors on thalamocortical glutamatergic neurons. J Neurosci 20:8846-8852.

Sesack SR, Deutch AY, Roth RH, Bunney BS (1989) Topographical organization of the efferent projections of the medial prefrontal cortex in the rat: an anterograde tract-tracing study with Phaseolus vulgaris leucoagglutinin. J Comp Neurol 290:213-242.

Stratford TR, Kelley AE (1999) Evidence of a functional relationship between the nucleus accumbens shell and lateral hypothalamus subserving the control of feeding behavior. J Neurosci 19:11040-11048.

Sutcliffe JG, de Lecea L (2000) The hypocretins: excitatory neuromodulatory peptides for multiple homeostatic systems, including sleep and feeding. J Neurosci Res 62:161-168.

Taber MT, Fibiger HC (1997) Activation of the mesocortical dopamine system by feeding: lack of a selective response to stress. Neuroscience 77:295-298

Taylor DM, McAskill R (2000) Atypical antipsychotics and weight gain: a systematic review. Acta Psychiatr Scand 101:416-432.

Terry P, Gilbert DB, Cooper SJ (1995) Dopamine receptor subtype agonists and feeding behavior. Obes Res [Suppl 4]3:515S-523S.

Uramura K, Funahashi H, Muroya S, Shioda S, Takigawa M, Yada T (2001) Orexin-a activates phospholipase C- and protein kinase $\mathrm{C}$-mediated $\mathrm{Ca}^{2+}$ signaling in dopamine neurons of the ventral tegmental area. NeuroReport 12:1885-1889.

Wetterling T, Mussigbrodt HE (1999) Weight gain: side effect of atypical neuroleptics? J Clin Psychopharmacol 19:316-321.

Willie JT, Chemelli RM, Sinton CM, Yanagisawa M (2001) To eat or to sleep? orexin in the regulation of feeding and wakefulness. Annu Rev Neurosci 24:429-458.

Wirshing DA, Wirshing WC, Kysar L, Berisford MA, Goldstein D, Pashdag J, Mintz J, Marder SR (1999) Novel antipsychotics: comparison of weight gain liabilities. J Clin Psychiatry 60:358-363.

Zhang W, Bymaster FP (1999) The in vivo effects of olanzapine and other antipsychotic agents on receptor occupancy and antagonism of dopamine D1, D2, D3, 5HT2A and muscarinic receptors. Psychopharmacology (Berl) 141:267-278. 